\title{
Esej o aktualność teorii Stuarta Halla w kontekście badań nad blogosferą
}

KEYWORDS

theory, topicality, blogosphere, Stuart Hall, pupilage
Knast Patrycja Kinga, Esej o aktualność teorii Stuarta Halla w kontekście badań nad blogosferą [Essay on validity of Stuart Hall's theory in the context of blogosphere studies]. Kultura - Społeczeństwo - Edukacja nr 1(13) 2018, Poznań 2018, pp. 143-152, Adam Mickiewicz University Press. ISSN 2300-0422. DOI 10.14746/kse.2018.13.11.

This essay is talking about topicality of Stuart Hall theory. Author of essay is contending that the Coding/encoding theory of Stuart Hall is still useful in works on blogosphere.

In essay author explained the Coding/encoding theory and notions of blogosphere. The author is arguing that that using Coding/encoding theory in works about blogosphere. The author is pointing prospective tesis up.

Spór o aktualność teorii nie jest nowy. Jest raczej stary, jak stara jest nauka i jej zdolność do tworzenia nowych teorii. O przestarzałych założeniach teoretycznych mówi się, mając na uwadze czas powstania oraz tło społeczne, jednak bywa, iż zapomina się o pozornie zmieniających się realiach. W przypadku teorii kodowania/dekodowania Stuarta Halla można właśnie mówić o takiej zmianie. Dlaczego? Otóż koncepcja ta jest zapośredniczonym przez Antonia Gramsciego przeniesieniem teorii Karola Marksa w obręb nauk o kulturze. Hall mówi nam o hegemonie, który zakorzeniony jest w kulturze i stosunkach społecznych, a uwidacznia się $\mathrm{w}$ przekazie telewizyjnym. Właśnie $\mathrm{w}$ tym miejscu może rodzić się pytanie o aktualność tej teorii. Jednak chciałabym już tu zasygnalizować, że obecnie odnajduję jej żywotność. Gdy zastanawiam się nad tym, kto i w jaki sposób tworzy przestrzeń Internetu, dostrzegam jej aktualność. Myśląc także o tym, co chce nam przekazać, 
widzę jej współczesność. Choć Internet stanowi bogatą przestrzeń komunikacji, jego formy są nieuporządkowane i nie ma w nich hierarchii. Jeśli jednak wziąć za wyznacznik liczebność, ośmieliłabym się twierdzić, iż blogów jest najwięcej. Blogosfera staje się hegemonem. Hegemonem w rozumieniu arytmetycznym i nadawczym, bowiem internetowy pamiętnikarz zdaje się dominować nad swoim czytelnikiem, organizując swoją własną przestrzeń narracji na dany temat oraz tworząc swoją własną ideologię. Można znaleźć więc wstępne argumenty na potwierdzające tę teorię.

\section{Teoria kodowania/dekodowania Stuarta Halla}

Teoria kodowania/dekodowania Stuarta Halla opisuje możliwości dekodowania treści przez odbiorców. Przystępując do rozważań nad odbiorem przekazu, powinno się zwrócić uwagę na sam program telewizyjny, który staje się początkiem dyskursu znaczącego. Kodowany jest on na poziomie językowych struktur znaczących, pochodzących od nadawców (Hall, 1987: 58-71). Odbiorcy zaś dokonują dekodowania tych struktur za pomocą swojej wiedzy i kompetencji im przypisanych, a wynikających na przykład z doświadczenia życiowego czy obycia kulturowego. Po zdekodowaniu przekazu tworzą oni własny jego obraz oparty na wcześniej wspomnianych czynnikach. W ten sposób mogą przyjąć różne podstawy odbiorcze: dominującą, negocjacyjną oraz opozycyjną (Hall, 1987: 58-71). Hall zauważa, iż

pierwsze z tych hipotetycznych nastawień to stanowisko dominująco-hegemonistyczne (...). Jeżeli widz (...) odbiera konotowane znaczenie w sposób całościowy i prosty oraz dekoduje przekaz w kategoriach tego kodu referencyjnego, według którego został on zakodowany, wówczas możemy powiedzieć, iż odbiorca operuje kodem dominującym. Drugie nastawienie, które chcielibyśmy wskazać, to stanowisko bądź kod wynegocjowany. (...) dekodowanie w wersji wynegocjowanej to mieszanina elementów przystosowanych i opozycyjnych. Uznaje prawomocność definicji hegemonistycznych w odniesieniu do znaczeń ogólnych (abstrakcyjnych), natomiast na bardziej konkretnym (zlokalizowanym) poziomie sytuacyjnym ustanawia własne prawa. Godzi się na uprzywilejowaną pozycję definicji wydarzeń, zastrzegając sobie jednocześnie prawo do przystosowywania ich do „warunków lokalnych", zajmowania stanowiska bardziej odpowiadającego własnej zbiorowości. (...) charakteryzuje się ona zróżnicowanym i niejednakowym stosunkiem do dyskursów (...). Na koniec: może być tak, że widz doskonale rozumie zarówno dosłowne, jak i konotacyjne meandry dyskursu, jednak dekoduje przekaz całkiem inaczej. Rozczłonkowuje przekaz zgodnie z kodem preferowanym po to, aby skomponować go ponownie według jakiś alternatywnych ram odniesienia. (...) Operuje czymś, co trzeba by nazwać kodem opozycyjnym. (Hall, 1987: 69-71) 


\section{Blogosfera jako przedmiot badań}

Podanie jednej uniwersalnej definicji bloga jest trudne. Niemal każdy z badaczy zajmujących się blogosferą lub, szerzej, badaniem Internetu konceptualizuje dziennik internetowy według własnych kryteriów (Więckiewicz, 2012: 51-65). Marta Więckiewicz wyjaśnia, że blog jest określany „jako dokument osobisty, składający się z datowanych wpisów prezentowanych w kolejności odwrotnej do chronologicznej, publikowany przez blogera na stronie internetowej" (Więckiewicz, 2012: 64-65).

M. Więckiewicz, w dalszej części swoich rozważań, wskazuje inne ważne cechy omawianego gatunku internetowego:

Datowane wpisy ułożone w kolejności odwrotnej do chronologicznej to łatwo rozpoznawalna cecha bloga odnosząca się do jego struktury (charakterystyczna dla dziennika internetowego jest dominacja antychronologii nad podziałem tematycznym). Pojęcie „dokument” wskazuje na to, iż blog jest gatunkiem niefikcjonalnym. Osobisty charakter dziennika internetowego łączy się z subiektywizmem [autora]. Określenie „dokument osobisty" sugeruje ponadto, że blogi mogą zostać zaliczone do kategorii dokumentu osobistego. Istotne w blogowaniu jest kontynuowanie procesu publikowania, a więc dodawanie kolejnych wpisów. Fakt publikacji na stronie internetowej wiąże się z cechą, jaką jest interaktywność. (...) W przypadku tego gatunku ważne jest stworzenie czytelnikom możliwości wyrażenia opinii na temat wpisu. (Więckiewicz, 2012: 64-65)

Definicja bloga według Dave’a Winera nieznacznie różni się od tej zaproponowanej przez Martę Więckiewicz:

Zgodnie z kryterium Dave’a Winera (...) blog musi mieć charakter osobisty, co oznacza, że jest pisany przez osobę prywatną lub grupę osób prywatnych (np. przyjaciół). Nie może być on prowadzony przez firmę lub jakąkolwiek inną instytucję. Pamiętnik sieciowy, jak sama nazwa wskazuje, jest umieszczany w sieci i istnieje tylko w niej, czyli jest wirtualny. Zdarzają się co prawda rzadkie publikacje blogów, są to jednak nieliczne przypadki i dzieje się tak najczęściej jedynie w momencie przerwania prowadzenia bloga przez blogera ${ }^{1}$. Następnym kryterium jest publikowanie i upublicznianie, czyli częste aktualizowanie, najczęściej raz dziennie, oraz udostępnianie czytelnikom zapisków w Internecie. Ostatnim warunkiem, które musi spełniać strona WWW w Internecie, aby można było nazwać ją blogiem, jest posiadanie przez nią publiczności, co uznaje się za jedną z bardziej znaczących cech bloga, odróżniającą dziennik sieciowy od zwykłego pamiętnika. Blog jest częścią wspólnoty. Nie może istnieć samodzielnie. (za: Bańczarowska, 2006: 663)

${ }^{1}$ Należy zwrócić uwagę, że obecnie blogi publikowane są w sposób tradycyjny. Przykładem jest książka Pauliny Stępień Mała wielka uczta, wydana nakładem wydawnictwa Muza. Publikacja powstała na podstawie bloga kulinarnego P. Stępień. W odniesieniu do dalszej części wywodu Dave’a Winera należy dodać, że blog Pauliny Stępień nie wygasł, jest redagowany na bieżąco. 
Poszukując definicji bloga, wystarczającej, by zrozumieć nie tylko ideę pamiętników internetowych, ale także fenomen portali lub platform blogowych, należy połączyć oba przytoczone powyżej wyjaśnienia. Uzupełniają się one w pewnych kwestiach, tworząc szerszą perspektywę badawczą.

Bloga można zatem zdefiniować w następujący sposób: niefikcjonalny dokument osobisty redagowany przez osobę lub grupę osób prywatnych ${ }^{2}$. Charakteryzuje się on antychronologią wpisów, która dominuje nad podziałem tematycznym. Pamiętnik internetowy cechuje również jego wirtualność, czyli udostępnianie na stronie internetowej. Ma on charakter ciągły, czyli odbywa się przynajmniej raz na dzień, tydzień czy miesiąc. O okresowości zamieszczania notatek decyduje bloger. Publikowanie wpisów rozumiane jest jako forma interaktywności pomiędzy pamiętnikarzem a jego czytelnikami. Poprzez strukturę pozwalającą odbierać informacje od użytkowników i reagować na ich treść można prowadzić dialog pomiędzy blogerem a użytkownikami, co w dalszej kolejności prowadzi do zbudowania wspólnoty pomiędzy nimi.

Każdy publikowany w Internecie blog ma swoją nazwę odnoszącą się bezpośrednio do autora lub do zamieszczanych na nim tekstów. Obok tytułu dziennika internetowego dominującą jego częścią jest tekst główny³. W tekście głównym zamieszczane są wpisy autora w kolejności odwrotnej do chronologicznej. Każda notatka ma odrębny tytuł oraz treść w formie tradycyjnej bądź multimedialnej. Na pierwszej stronie internetowego dziennika jego autor zamieszcza także zakładki odsyłające odbiorców do archiwum oraz księgi gości. Wśród elementów znajdujących się na blogu można wyróżnić: miejsce na komentarze pochodzące od czytelników; hiperłącza odsyłające do innych blogów, lubianych bądź polecanych przez autora; dane personalne twórcy dziennika internetowego; zdjęcia; dewizę, która przyświeca blogerowi; rzadziej licznik wejść ${ }^{4}$.

O wyglądzie i budowie bloga często decyduje szata graficzna udostępniana przez serwery blogowe ${ }^{5}$, dlatego też dzienniki internetowe na nich umieszczane

2 Warto zastanowić się, czy zatem blogi polityków, mając na uwadze tę tezę, są nadal blogami. Należałoby przeanalizować ich treść pod kątem zawartych w nich poglądów, i zastanowić się, czy należą one do danego polityka, czy też całej partii.

${ }_{3} \mathrm{~W}$ artykule Blog jako dokument osobisty - specyfika dziennika prowadzonego w Internecie Marta Olcoń miejsce, w którym umieszczane są wpisy, nazywa tekstem głównym. Podążając za terminologią M. Olcoń, autorka niniejszej pracy, posługiwać będzie się określeniem 'tekst główny'. Artykuł dostępny jest pod adresem: http://www.depot.ceon.pl/bitstream/handle/123456789/1442/Blog\%20jako\%20dokument\%20osobisty_Olco\%C5\%84_Marta.pdf?sequence=1, dostęp: 4.07.2017, s. 4 .

${ }^{4}$ Ibidem, s. 4-5.

${ }^{5}$ Warto zobaczyć kilka lub kilkanaście blogów znajdujących się na popularnych serwerach (np. blox.pl czy bloog.pl), by zaobserwować opisywane kwestie. 
są do siebie graficznie podobne. Pośród serwerów udostępniających miejsca do pisania internetowego pamiętnika są i takie, które pozwalają użytkownikom dokonywać niewielkich zmian w tak zwanych skórkach ${ }^{6}$. W kwestii struktury i formy bloga najwięcej swobody mają ci blogerzy, którzy tworzą własne strony WWW i na nich publikują swoje zapiski.

Precyzyjnego wskazania problematyki poruszanej $\mathrm{w}$ dziennikach internetowych można dokonać poprzez wyznaczenie typologii blogów ze względu na treść. Według tego kryterium można wyróżnić pięć kategorii blogów (Więckiewicz, 2012: 125). W pierwszej jako główny wątek wskazuje się życie prywatne (Więckiewicz, 2012: 126). „Blogerzy wykorzystują [Internet] do przedstawienia swojego życia prywatnego: opisują rozwój dzieci, opowiadają o funkcjonowaniu rodzin, analizują problemy uczuciowe" (Więckiewicz, 2012: 136); osoby piszące internetowy pamiętnik zwierzają się także z problemów w pracy, życia intymnego czy ze swojego obecnego stanu psychicznego. Autorzy blogów sklasyfikowanych w drugiej kategorii, problematyce kulturalnej (Więckiewicz, 2012: 137), zajmują się szeroko rozumianą kulturą. Zatem piszą oni recenzje powieści, wiersze, opowiadania. Blogerzy mogą być literatami ${ }^{7}$, a internetowy pamiętnik umożliwia im znalezienie odbiorców (Więckiewicz, 2012: 144). Kolejny typ dzienników internetowych, „blogi dotyczące polityki” (Więckiewicz, 2012: 145), zawiera wpisy omawiające sprawy bieżące z życia politycznego. Ich autorami są politycy, publicyści oraz osoby tym zainteresowane. Blogi tej grupy pokazują pluralizm poglądów w społeczeństwie oraz stanowią miejsce wymiany opinii. Kolejna kategoria,

blogi dotyczące nowych technologii (...) koncentrują się zazwyczaj wokół takich tematów jak: Internet (programowanie, kodowanie, tworzenie stron internetowych w zgodzie ze standardami użyteczności i dostępności, pozycjonowanie stron WWW w wyszukiwarkach, przeglądarki, domeny internetowe), komputery (programy komputerowe, systemy operacyjne, sprzęt komputerowy, administrowanie sieciami komputerowymi) rzadziej pojawiają się zagadnienia związane z telefonią komórkową i fotografią cyfrową. (...) Tym, co cechuje znaczną grupę dzienników internetowych poświęconych owym technologiom, jest hermetyczny język, niezrozumiały dla przypadkowych czytelników. (Więckiewicz, 2012: $156)^{8}$

${ }^{6}$ Skórkami nazywane są szaty graficzne udostępniane jako gotowe szablony.

${ }^{7}$ Jako przykład takiego wykorzystania bloga może posłużyć dziennik internetowy Katarzyny Michalak, która zarówno recenzuje powieści innych autorów, jak i opisuje swoje własne. Zob. http:// katarzynamichalak.blogspot.com/, dostęp: 7.07.2016.

${ }^{8}$ Dalej autorka zauważa, że blogi te pomagają rozwiązywać problemy informatyczne czy propagują wiedzę o IT. 
Ostatnią stypologizowaną grupą są blogi wielotematyczne (Więckiewicz, 2012: 155). Nie można wskazać jednego tematu poruszanego przez autora w swoim dzienniku. By odbiorcy łatwiej było się poruszać po takim pamiętniku, twórca kategoryzuje swoje wpisy według kryterium, jakim są poruszane przez niego wątki. Często osoba pisząca bloga nie stara się przypisać swojej notatki do konkretnej kategorii. Dzienniki wielotematyczne mogą stanowić odbicie ról społecznych człowieka oraz doświadczeń im towarzyszących (Więckiewicz, 2012: 159-166).

Warto również zauważyć, że blog jest odzwierciedleniem postawy życiowej autora. Zatem tematyka zależy od jego upodobań, a klasyfikacja blogów może wskazywać, „jakimi ścieżkami” poruszają się osoby tworzące blogosferę.

Blogi w przeważającej części są ogólnodostępnym miejscem wyrażania swoich przemyśleń oraz dialogu w Internecie ${ }^{9}$. Tego typu komunikacja determinuje wybór odpowiedniego kodu. Wpisy autora bloga oraz jego czytelników powinny mieć charakter normatywny, w uzasadnionych przypadkach muszą być zgodne z uzusem. Pożądane jest, by dyskusje pomiędzy odbiorcami dziennika internetowego oraz między czytelnikami a blogerem odbywały się zgodnie z przyjętą $\mathrm{w}$ świecie realnym konwencją, zobowiązującą ich do powściągliwości i stosowania etykiety, a w komunikacji elektronicznej netykiety. Sam język, oprócz wskazanej powyżej konwencji, może być różnorodny ze względu na kompetencje językowe blogera i jego odbiorców.

Interaktywność blogów ułatwia kontakt między nadawcą komunikatu a jego odbiorcą. Porozumiewają się oni najczęściej za pomocą komentarzy zamieszczanych pod notatką oraz możliwości uzyskania odpowiedzi na zamieszczone uwagi. Dzięki opcji dodawania komentarzy czytelnicy mogą oddziaływać na autora, na przykład sugerując mu temat kolejnego wpisu lub domagając się notatki o konkretnym problemie. Takie oddziaływania sprawiają, że czytelnik może wejść w rolę autora. Granica pomiędzy nimi staje się niewyraźna, co powoduje, iż teoretycznie może dojść do odwrócenia ról. Jednak należy mieć na uwadze, że to bloger dominuje nad czytelnikiem, gdyż to on jest twórcą dziennika (Więckiewicz, 2012: 23-255).

By narodziła się jakakolwiek relacja pomiędzy autorem bloga a jego odbiorcą, niezbędne jest wskazanie prawdopodobnych, psychologicznych przyczyn powstania blogów, mianowicie autoprezentacji i ekshibicjonizmu (Więckiewicz, 2012). Autoprezentacja towarzyszy ludziom w każdej sytuacji prywatnej i publicznej, nie-

9 Nie wszystkie blogi są ogólnodostępne. Niektórzy blogowicze mogą tworzyć i dostarczać odbiorcom kody dostępu do swoich blogów. Szerzej na ten temat w: Więckiewicz, 2012. 
mal od narodzin aż do samej śmierci. „Autoprezentacja to proces kontrolowania przez jednostkę sposobu, w jaki jest postrzegana przez otoczenie" (Leary, 2012: 27). Definicję zaproponowaną przez Marka Leary'ego można w prosty sposób "przenieść na grunt” blogosfery. Mianowicie jednostka, czyli bloger, zamieszcza swoje wpisy w dzienniku internetowym, za pomocą notatki ujawnia się otoczeniu, czyli innym autorom oraz czytelnikom. Tematyka notatek może dotyczyć życia rodzinnego, intymnego, zawodowego, jest dowolnie ustanawiana przez twórcę. Za pomocą wpisów oraz przy wykorzystaniu specjalnego działu - o mnie/o auto$r z e$ - dokonuje prezentacji samego siebie. Podobnie formą autoprezentacji mogą być nazwa bloga czy nick ${ }^{10}$ autora (Więckiewicz, 2012: 200). W przypadku bloga i jego narzędzi autoprezentacja może być zjawiskiem o szerokim oddziaływaniu na dwóch płaszczyznach: świadomej i nieświadomej. Nie jest możliwe jednoznaczne rozgraniczenie świadomej i nieświadomej autoprezentacji blogera. Jednak można wskazać przykład bloga, w którym autorki prowadzą świadomą autoprezentację, stylizowaną na subkulturę Emo. Jest to obecnie nieaktualizowany blog zatytułowany Emo-martynka ${ }^{11}$. Autorki wskazanego dziennika internetowego podawały się za około piętnastoletnią dziewczynę należącą do subkultury Emo. Blog był prowadzony w stylistyce graficznej i językowej nawiązującej do wskazanej subkultury, jednak jego autorki były osobami dorosłymi.

Drugi możliwy motyw tworzenia blogów to ekshibicjonizm (Więckiewicz, 2012: 216-217). W tym przypadku, jeśli chce się używać tego pojęcia w odpowiednim kontekście, należy odwoływać się raczej do potocznego rozumienia tego terminu. Według Encyklopedii PWN ekshibicjonizm potocznie oznacza skłonność do ujawniania własnych przeżyć i problemów ${ }^{12}$. $Z$ definicji tej można wysnuć wniosek, iż bloger ma predyspozycje do uzewnętrzniania swoich doświadczeń oraz trudności życiowych.

\section{Kodownie/dekodowanie bloga}

Powróćmy do rozważań prowadzonych na wstępie. Zauważone zostało, że internetowy pamiętnikarz, zamieszczając swoje wpisy, może stać się hegemonem wobec swego odbiorcy, wypowiadającego się i dekodującego jego przekaz w ko-

\footnotetext{
${ }^{10}$ Nick, czyli internetowy pseudonim autora internetowego pamiętnika.

11 Zob. http://emo-martynka.blog.onet.pl.

${ }^{12}$ http://encyklopedia.pwn.pl/haslo.php?id=4008135, dostęp: 9.07.2016.
} 
mentarzach. Pozostaje więc omówić, w jaki sposób teoria Halla wciąż wydaje się aktualna.

Po pierwsze, warto zaznaczyć, że w omawianej płaszczyźnie Internetu należy dokonać pewnych zmian. Hall pod pojęciem przekazu rozumiał program telewizyjny. Na potrzeby badań nad blogami należy pod tym terminem pojmować notatki blogowe (wpisy). To one rozpoczynają dyskurs znaczący. Kodowanie pamiętnikarza może mieć, podobnie jak w teorii brytyjskiego badacza, charakter językowy, wizualny lub dźwiękowy (lub wszystkie razem). Może tym samym posiadać struktury znaczące - takie jak: ogólne udostępnianie w Sieci, interaktywność, chęć autoprezentacji czy ekshibicjonizm - które wynikają z budowy samego bloga oraz postawy blogera. Właściwie kompetencje w sensie posiadanej wiedzy internetowego pamiętnikarza są mniej istotne, podobnie jak możliwości komunikacyjne. Zakłada się niejako z góry, że autor wpisu opisuje swoje doświadczenie życiowe bądź przemyślenia na wybrany przez siebie temat i w ten sposób niejako a priori zakłada się, iż jest uprawniony do wygłaszania sądów. W swojej teorii brytyjski badacz mówi o relacjach/stosunkach produkcji (Hall, 1987: 61) rozumianych jako ideologia. W przypadku bloga, a zgodnie z definicją słowa „ideologia”"13 będą nimi pomysły, idee czy spostrzeżenia zawarte we wpisach. Nie należy zapominać również o infrastrukturze, która na potrzeby tej teoretycznej modyfikacji jest rozumiana jako korzystanie z możliwości edycyjnych, jakie daje Sieć, szata graficzna oraz opcja wstawiania komentarzy.

Z powyższych rozważań wynika zatem, iż blog zamieszczany w Internecie spełnia wszystkie kryteria, które wymienił S. Hall. Ma publiczność, czyli osoby czytające i komentujące jego treść. Tak więc możliwe jest przeprowadzenie badania, które scharakteryzuje relacje pomiędzy nadawcą - blogerem a odbiorcą - czytelnikiem, komentatorem.

Jednakże, prowadząc badania za pomocą zmodyfikowanej teorii kodowania/ dekodowania, należy dobierać takie pamiętniki sieciowe, które są komentowane. To twierdzenie powinno zostać potraktowane jako założenie wstępne. Nie obniża ono jednak wartości prowadzonych badań, dlatego że, przyjmując pewne założenia teoretyczne i posługując się nimi, naukowiec godzi się na rozwiązania tego typu.

Po drugie, blog mający swoich czytelników staje się zarówno miejscem dekodowania wpisów, jak również udostępnia przestrzeń, gdzie może dojść do ujawnienia postawy odbiorczej adresata treści. Komentujący może akceptować treść przekazu, negocjować jego znaczenie lub zupełnie odrzucić. W tej sferze Sieć daje

${ }^{13}$ Zob. http://sjp.pwn.pl/sjp/ideologia;2465523.html, dostęp: 9.07.2016. 
podobne możliwości do tych dostarczanych przez telewizję. Nadto ma jeszcze jedną zaletę, badacz ma bowiem zebrane w jednym miejscu opinie odbiorców, nie musi ich poszukiwać i tworzyć dodatkowych grup fokusowych, prowadzić wywiadów pogłębionych etc.

\section{Podsumowanie}

Współczesny namysł metodologiczny nad teorią S. Halla pozwala wprowadzić pewne modyfikacje i dostosować ją do potrzeb badania relacji pomiędzy blogerem a jego czytelnikiem, podobnie jak to było w przypadku nadawcy programu telewizyjnego i jego odbiorcy. Wprowadzenie tych zmian wskazuje, iż teoria Halla jest nadal aktualna i może być wykorzystywana w badaniach prowadzonych w Internecie. Ponadto wskazuje także jej łatwość w aplikowalności, po przyjęciu proponowanego założenia wstępnego.

Przeanalizowanie blogosfery w ramach refleksji nad aktualnością teorii kodowania/dekodowania stawia dodatkowe pytania. Mianowicie warto zastanowić się, czy w badaniach nad przekazem hegemonicznym zmiany są na tyle zaawansowane, by mówić o zdezaktualizowaniu się tej teorii. Należałoby także poczynić rozważania nad współczesnym hegemonem (hegemonami) i jego (ich) rolą. Dodatkowo zauważyć można przystawalność teorii brytyjskiego uczonego do nowego obszaru badań. Kompatybilność ta rodzi pytanie o charakter i stopień zaawansowania zmian, jakie zaszły od pierwszej jej aplikacji do teraz.

Podobnych pytań, choćby do tych przywołanych powyżej, nasuwa się znacznie więcej, niemniej jednak nie one stanowiły przedmiot niniejszego eseju. Założeniem pracy było bowiem wypracowanie argumentów na rzecz aktualności teorii kodowania/dekodowania Halla.

\section{Literatura}

Bańczarowska M. (2006). Blogi - współczesne pamiętniki. [W:] I. Kamińska-Szmaj, T. Piekota, H. Zaśko-Zielińska (red.). Język a komunikacja. 12. Oblicza komunikacji. Perspektywy badań nad tekstem, dyskursem i komunikacją. Kraków.

Hall S. (1987). Kodowanie i dekodowanie, tłum. W. Lipnik, I. Siwiński. „Przekazy i Opnie” nr 1-2. http://emo-martynka.blog.onet.pl http://encyklopedia.pwn.pl/haslo.php?id=4008135, dostęp: 9.07.2016.

Leary M. (2012). Wywieranie wrażenia na innych. O sztuce autoprezentacji, tłum. A. Kamcjor, M. Kamcjor. Gdańsk. 